\title{
Effect of Compactive Efforts on Hydraulic Conductivity of Black Cotton Soil Treated with Cassava Peel Ash
}

\author{
Adeyemo, K. A., Yunusa, G. H. and Bello, A. A.
}

\begin{abstract}
This paper presents the results of laboratory investigation carried out on the effect of compactive efforts on the hydraulic conductivity of black cotton soil treated with Cassava Peel Ash (CPA) at 0, 4, 8, 12, 16, 20 and 24\% CPA treatment. Index properties, hydraulic conductivity and cation exchange capacity tests were carried out. Specimens were prepared at moulding water contents $2 \%$ dry, OMC, $2 \%$ wet and $4 \%$ wet of optimum moisture content using British Standard Light (BSL), British Standard Heavy (BSH) and West African Standard (WAS) compactive efforts. The results show that hydraulic conductivity value generally decreases as the CPA concentration is increased in the blend. At optimal 16\% CPA treatment level, hydraulic conductivity values are 1.74 $\times 10^{-8}, 1.40 \times 10^{-8}$ and $8.42 \times 10^{-9} \mathrm{~cm} / \mathrm{s}$ for BSL, WAS and BSH energy levels. Cation exchange capacity (CEC) test was also conducted to further investigate the water holding capacity of the natural and treated specimens; the CEC indicates that CPA had positive contribution on the hydraulic conductivity of the treated specimens especially as CPA content is increased. This study revealed that hydraulic conductivity decreases to its minimum at higher compactive effort.
\end{abstract}

Keywords: Hydraulic conductivity, cassava peel ash, compactive efforts, cation exchange capacity, moulding water content.

\section{Introduction}

Black cotton soils contain troublesome expansive clay mineral deposits with high swelling and shrinkage potentials [22]. In Nigeria, black cotton soils cover about 104000 $\mathrm{km}^{2}$ of the North-East; these include roads linking the country with countries like Chad Republic, Niger and Cameroun [16, 19]. They possessed high expansive and shrinkage ability that are usually induced by moisture variation, with resulting cracks in its dry state. These undesirable behaviours of black cotton soil are attributed to the presence of expansive clay mineral (Montmorillonite) in abundant amount, and can cause structure failure when

\footnotetext{
Adeyemo, K. A. and Bello, A. A. (Department of Civil Engineering, Osun State University, Osogbo, Nigeria)

Yunusa, G. H. (Department of Civil Engineering, Bayero University, Kano, Nigeria)

Corresponding author's email address: adeyemokazeem59@gmail.com
}

engineering facilities are placed on it due to excessive settlement and cracking. According to $[20,24]$, indications are that the soil properties can be improved by modification/stabilization using additives.

Cassava Peel Ash (CPA) is obtained by calcination of agricultural wastes (cassava peels) emanating from cassava processing [9]. According to [21], the volume of wastes generated in the world has increased over the years and agricultural wastes such as rice husk, yam peels, corn cob, groundnut shell, and cassava peels etc. constitute a major component; Nigeria, being the highest producer of cassava in Africa, has the highest volume of Cassava Peel [12]. Therefore, it is expected that more agricultural wastes from cassava processing will be produced, one of the most appropriate ways of dealing with such wastes in order to minimize the environmental hazard that they pose is to look into the 
possibility of their re-utilization. In recent time several investigations have been conducted on agricultural solid wastes resulting from yam, date, banana, cocoa, cassava, rice husk, groundnut etc. [28], to study their effects on engineering properties of soil. This is due to the fact that they constitute environmental hazards and could have their usefulness in soil stabilization/modification. Therefore, investigating the impact of Cassava Peel Ash (CPA) on black cotton soil as modifier could help in reducing and subsequent utilization of these wastes.

\section{Materials and Method}

\section{A. Materials}

1) Black Cotton Soil - The black cotton soil samples were collected from Deba town in
Yamaltu-Deba local government area (latitude $10^{\circ} 13^{\prime} \mathrm{N}$ and longitude $11^{\circ} 23^{\prime} \mathrm{E}$ ) of Gombe state, through the disturbed method of sampling. It was collected at a depth between $0.5-1.0 \mathrm{~m}$. The samples were sealed in plastic bags and thereafter transported to the Soil Mechanics Research Laboratory of the Department of Civil Engineering, Bayero University, Kano for testing. Reports from previous works reveal that montmorillonite is the dominant clay mineral in the soil from the study area $[2,20,24]$. The soil is classified as A7-6 (31) according to AASHTO classification system [1], while it is classified as $\mathrm{CH}$ according to Unified Soil Classification System [5]. The index properties of the soil sample are summarized in Table 1 and they are in line with the reports of $[10,20,26]$ for soils from the study area.

Table 1: Properties of the Natural Black Cotton Soil

\begin{tabular}{lc}
\hline \multicolumn{1}{c}{ Property } & Quantity \\
\hline Natural moisture content, \% & 9.7 \\
Specific gravity & 2.52 \\
Liquid limit, \% & 62 \\
Plastic limit, \% & 24 \\
Plasticity index, \% & 38 \\
Linear shrinkage, \% & 17.4 \\
\% passing BS No. 200 sieve & 78.8 \\
Free swell, \% & 68 \\
AASHTO classification & A-7-6 (31) \\
USCS classification & $\mathrm{CH}$ \\
Activity & 9.9 (active clay) \\
Cation exchange capacity, cmol/kg & 9.54 \\
pH & 7.1 \\
Colour & Dark Grey \\
Dominant Clay Mineral & Montmorillonite \\
\hline
\end{tabular}

Table 2: Percentage Oxide Composition of Cassava Peel Ash.

\begin{tabular}{cc}
\hline Chemical Constituent & Percentage Composition \\
\hline $\mathrm{SiO}_{2}$ & 54.40 \\
$\mathrm{Al}_{2} \mathrm{O}_{3}$ & 11.86 \\
$\mathrm{Fe}_{2} \mathrm{O}_{3}$ & 5.80 \\
$\mathrm{CaO}$ & 10.4 \\
$\mathrm{MgO}$ & 0.13 \\
$\mathrm{SO}_{3}$ & 0.45 \\
$\mathrm{~K}_{2} \mathrm{O}$ & 13.10 \\
$\mathrm{Na}_{2} \mathrm{O}$ & 1.04 \\
$\mathrm{LOI}$ & 2.82 \\
\hline
\end{tabular}


2) Cassava Peels Ash - The cassava peel used in this study was collected from a cassava processing factory located at Oke-Bale in Osogbo Local Government Area of Osun State. The peels were sun dried, burnt into ashes in open air and then transferred into an electric furnace where it is calcined at $700^{\circ} \mathrm{C}$ for 90 minutes [7]. At these conditions $\left(700^{\circ} \mathrm{C} / 90\right.$ minutes), according to [27] the CPA contains combination of silica, alumina, and ferric oxide greater than $70 \%$, thus it possess pozzolanic reactivity according to ASTM standard for a good pozzolana [4]. The ash was sieved through BS Sieve $75 \mu \mathrm{m}$, collected and stored under room temperature until it is needed to prevent moisture and contaminations from other materials. The oxide composition of CPA prepared as reported by [27] was determined using $\mathrm{X}$-ray Fluorescence (XRF) analysis, the test was conducted at the National Geosciences Research Laboratory (NGRL), Kaduna, and the percentage oxide composition is presented in Table 2 .

\section{B. Methods}

\section{1) Index Properties}

Particle size distribution, specific gravity of soil solids and Atterberg limit tests conducted on the soil samples were in line with the procedures outlined in British Standard Institution [8].

\section{2) Compaction}

This involves moisture - density relationship and hydraulic conductivity tests carried out using British Standard Light (BSL), West African Standard (WAS) and British Standard Heavy (BSH) compactive efforts in accordance with $[8,18]$. The specimens were prepared by passing air - dried soil sample through BS sieve with $4.76 \mathrm{~mm}$ aperture as outlined by [13] as well as [3] and then mixed with $0,4,8,12,16$, 20 and $24 \%$ CPA by weight of dry soil used.

\section{3) Hydraulic Conductivity}

This was measured through the falling head condition as recommended by Head (1992) for fine grained soil. The specimens were compacted at different moulding water contents ( $2 \%$ dry, OMC, $2 \%$ wet and $4 \%$ wet of OMC) using BSL, WAS and $\mathrm{BSH}$ compactive efforts. In order to allow for the full saturation of each sample, it was soaked in a water tank for at least 48 hours. After saturation, the test sample was connected to a permeant liquid (distilled water). Observed changes in water heads due to permeation after time, $\mathrm{t}$ (hours) intervals were measured and recorded. Permeation was aborted when steady state conditions were observed in the hydraulic conductivity values, at least after 8 hours.

\section{4) Cation Exchange Capacity (CEC)}

Cation exchange capacity tests were performed on natural and treated black cotton soil to further quantify its water holding potential. The capacity of a soil to retain some cations such as Calcium $\left(\mathrm{Ca}^{2+}\right)$, Magnesium $\left(\mathrm{Mg}^{2+}\right)$, Potassium $\left(\mathrm{K}^{+}\right)$, Sodium $\left(\mathrm{Na}^{+}\right)$, Aluminium $\left(\mathrm{Al}^{3+}\right)$ and Iron $\left(\mathrm{Fe}^{2+}\right)$ is called cation exchange capacity [11]. These cations are held by electrostatic forces; the negative soil particles in clayey or organic soil attract the positive cations. This simply means that the CEC of a soil is the aggregate sum of interchangeable cations that the soil can retain. According to 
[11], higher CEC is an indication of high clay content in the soil and thereby possessing greater water retention capacity than low CEC soils.

\section{Results and Discussion}

\section{A. Atterberg limits}

The Atterberg limits of cassava peels ash stabilized black cotton soil was studied and their variations with cassava peel ash contents $(0,4,8,12,16,20$, and $24 \%)$ are as shown in Figures 1 and 2. According to [6], if liquid limit of soil is between $50 \%$ and $70 \%$.This shows that the sample has high plasticity. The addition of Cassava peels ash in 4, 8, 12, 16, 20 and $24 \%$ to the sample caused changes in the plasticity indices and linear shrinkage of the sample, as shown in Figures 1 and 2. The reductions in plasticity indices as shown in Figure 1 are indicators of soil improvement [7].

\section{B. Compaction Characteristics}

The summary of the maximum dry density and optimum moisture content of varying CPA content using three different compactive efforts (BSL, WAS, and BSH) are shown Figures 3 and 4.

\section{1) Maximum Dry Density}

From Figure 3, the MDD of the natural soil are $1.65,1.75$ and $1.87 \mathrm{Mg} / \mathrm{m}^{3}$ for BSL, WAS, and $\mathrm{BSH}$ respectively. The addition of CPA in 4,8 , 12, 16, 20 and $24 \%$ brought about some changes in MDD values as shown in Figure 3. For the BSL compactive effort, the MDD gradually increase with increasing $\mathrm{CPA}$ content up to peak at $16 \% \mathrm{CPA}$. For the $\mathrm{BSH}$ compactive effort, there is increase in the MDD value at 4\% CPA, then a sudden decrease at $8 \%$ CPA after which gradual increase was noticed up to the peak value at $16 \%$ CPA with no significant changes afterwards. The WAS compactive effort also follows the same trend as in the $\mathrm{BSH}$ compactive effort but with significant changes after the peak value at $16 \% \mathrm{CPA}$. It was viewed

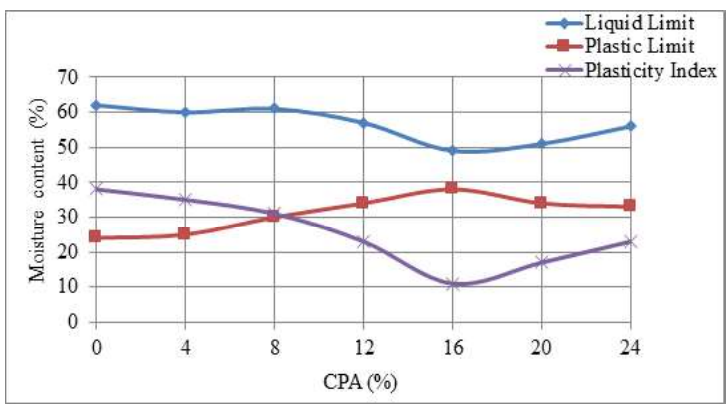

Figure 1: Variation of Atterberg Limits with CPA Content

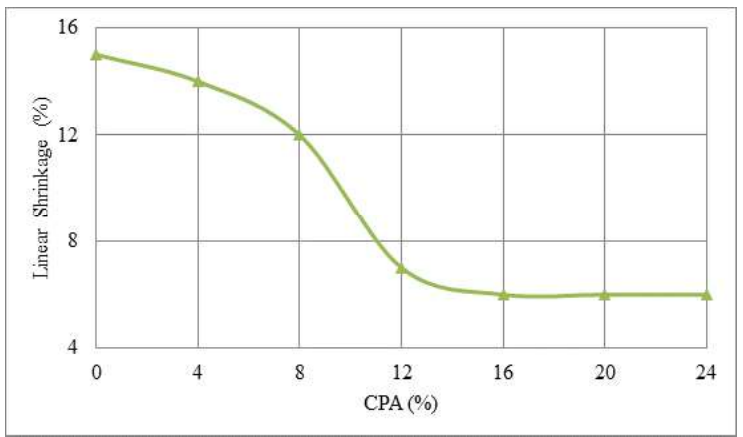

Figure 2: Linear Shrinkage with CPA Content

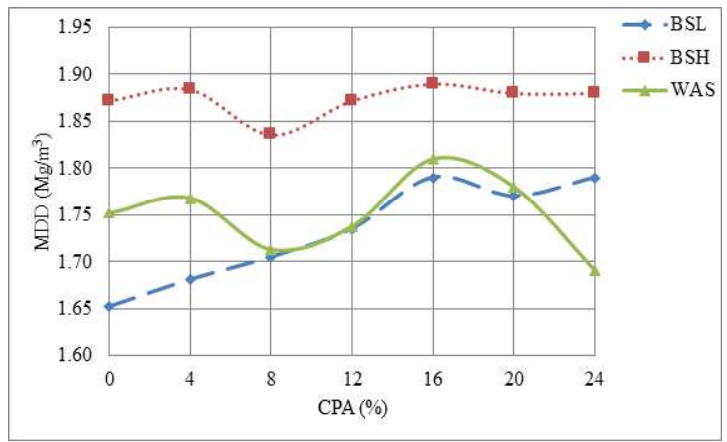

Figure 3: Variation of Maximum Dry Density with CPA Content 
that the MDD increase was as a result of ash particles filling the voids within the specimen during compaction $[2,17]$, while the decreasing trend after the peak value may be as a result of the continuous replacement of the natural soil with low specific gravity ash particles as the CPA concentration keep increasing in the blend $[2,15]$.

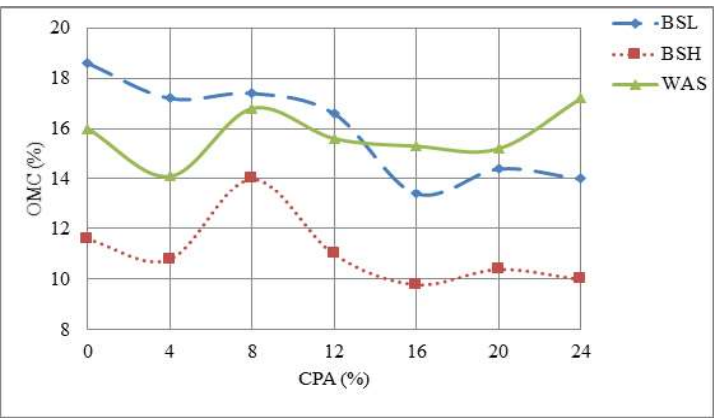

Figure 4: Variation of Optimum Moisture Content with CPA Concentration

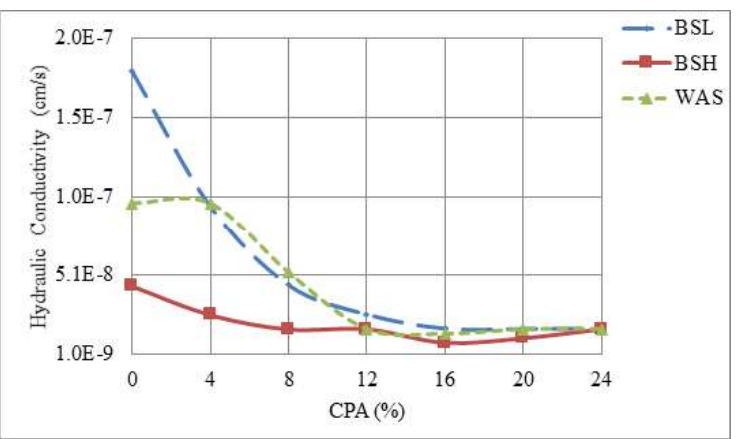

Figure 5: Variation of Hydraulic Conductivity with CPA Content

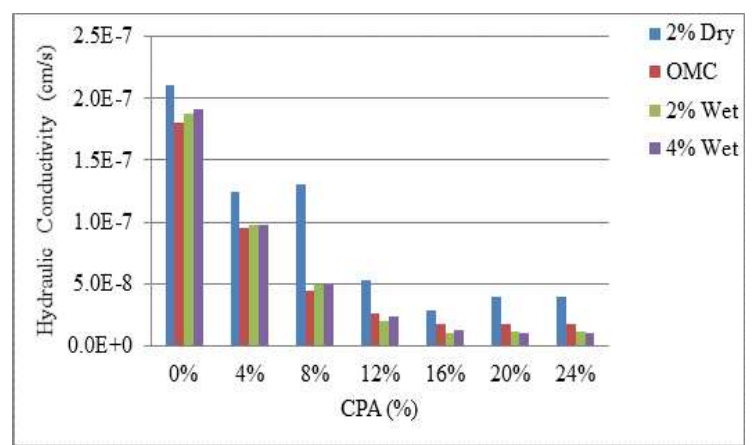

Figure 6: Variation of Hydraulic Conductivity with Compaction Water Content Relative to Optimum for BSL Compactive Effort.

\section{2) Optimum Moisture Content}

From Figure 4, the OMC of the natural soil are 18.6, 16.0 and $11.6 \%$ for BSL, WAS, and BSH respectively. Increasing the CPA content in 4 , 8, 12, 16, 20 and $24 \%$ brought about some changes in OMC values as shown in Figure 4. For the BSL compactive effort, the OMC gradually decrease with increasing CPA content up to minimum at $16 \%$ CPA. For the $\mathrm{BSH}$ compactive effort, there is decrease in the $\mathrm{OMC}$ value at $4 \% \mathrm{CPA}$, then a sudden increase at $8 \%$ CPA after which gradual decrease was noticed up to the minimum value at $16 \% \mathrm{CPA}$ with no significant change afterwards. The WAS compactive effort also follows the same trend as in the BSH compactive effort but with significant change after the minimum value at $20 \%$ CPA. The decreasing trend observed in $\mathrm{OMC}$ with increasing CPA contents complies with past researches $[2,15,17]$. The OMC chart shows a sudden rise at $8 \% \mathrm{CPA}$ content; this sudden rise could be due to increasing water demand by the cations in the CPA and the black cotton soil clay particles for hydration purpose. While the decrease in OMC beyond $8 \%$ CPA treatment level could be as a result of cation exchange $[2,17]$ causing flocculation of the clay particles.

\section{Hydraulic Conductivity}

The variation of hydraulic conductivity values of black cotton soil with various mix content of CPA compacted at OMC of three different compactive energies is shown in Figure 5. Generally, the hydraulic conductivity values decrease with increasing CPA content for all the compactive energies. The BSL shows significant changes up to $16 \% \mathrm{CPA}$ content after which there are no pronounced changes 
through 20 and 24\% CPA contents. But, both the WAS and BSH show notable decrease in hydraulic conductivity values up to $16 \% \mathrm{CPA}$ content and significant increase at 20 and $24 \%$ afterwards. The decrease in hydraulic conductivity is attributed to void reduction as ash particles fill the voids within the specimen $[2,17]$.

The effect of compaction water content on hydraulic conductivity was also investigated. The variations of hydraulic conductivity values versus compaction water content relative to the optimum values are shown in Figures 6, 7 and 8 . In almost all the cases considered, the hydraulic conductivity obtained its lowest values at the wet side of optimum moisture content, especially at $2 \%$ wet of OMC for most of the specimen. But exceptions were noticed in some specimen $(0,4,8 \%$ BSL; $0,4,12 \%$ WAS and $0,4 \%$ BSH compactive efforts), where the lowest values of hydraulic conductivity were recorded at OMC. The increasing moulding water content brings about reduction of voids by facilitating sliding of particles past one another during compaction and de-flocculation of the particle structure. This conforms with works reported by $[23,25]$.

\section{Cation Exchange Capacity (CEC)}

The variation of CEC of the black cotton soil with CPA content is shown in Figure 9. The CEC generally increases from $9.54 \mathrm{cmol} / \mathrm{kg}$ at $0 \%$ CPA content to the peak value 30.82 $\mathrm{cmol} / \mathrm{kg}$ at $20 \% \mathrm{CPA}$ content. The increase in $\mathrm{CEC}$ is as a result of the increasing electrostatic attraction between the negatively charged clay particles and increasing cation concentration as the CPA content is increased. It can therefore

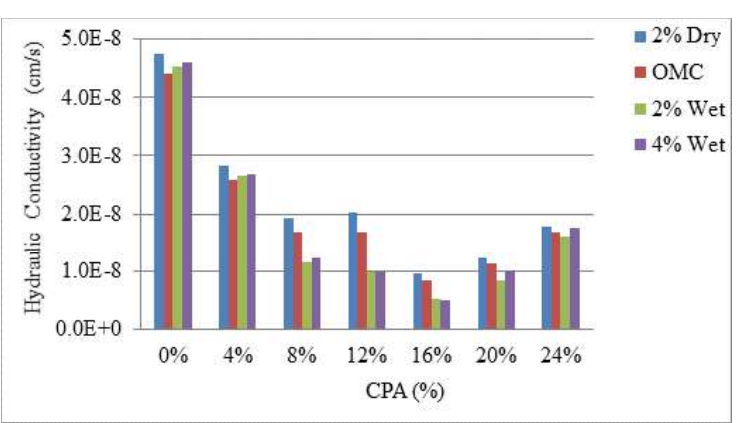

Figure 7: Variation of Hydraulic Conductivity with Compaction Water Content Relative to Optimum for BSH Compactive Effort.

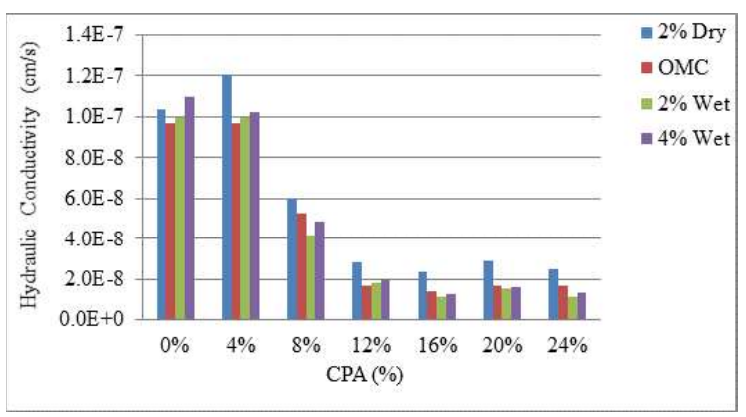

Figure 8: Variation of Hydraulic Conductivity with Compaction Water Content Relative to Optimum for WAS Compactive Effort.

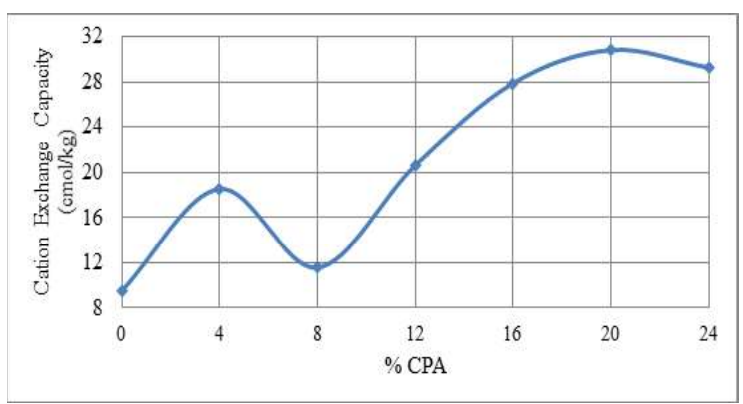

Figure 9: Variation of CEC with CPA Content.

be deduced that as the CPA content of the soil is increased, the water holding capacity also increases.

\section{Conclusion}

The black cotton soil used in this study is classified as A-7-6 (31) and $\mathrm{CH}$ according to AASHTO and USCS classification systems respectively. The MDDs of the natural soil are: 
1.65, 1.87 and $1.75 \mathrm{Mg} / \mathrm{m}^{3}$ with their corresponding OMC values; 18.6, 16.0 and $11.6 \%$ for BSL, WAS and BSH respectively. At these MDDs and OMCs, the hydraulic conductivity values are $1.80 \mathrm{E}-07,9.71 \mathrm{E}-08$ and $4.40 \mathrm{E}-08 \mathrm{~cm} / \mathrm{s}$ for BSL, WAS and BSH energy levels respectively. A trend of increasing plastic limits up to $16 \% \mathrm{CPA}$ and decrease in the liquid limit and linear shrinkage down to $16 \%$ CPA was observed after which no significant changes occur. The results of compaction tests generally revealed a trend of increasing MDD with corresponding decrease in OMC with increasing CPA content up to $16 \%$ CPA content for the three energy levels considered.

Based on the hydraulic conductivity test results, it can be concluded that the specimens considered possessed hydraulic conductivity less than or equal to $1.0 \times 10^{-7} \mathrm{~cm} / \mathrm{s}$ when:

- The CPA content ranges between 4 $24 \%$ for BSL, $0-24 \%$ for WAS and $\mathrm{BSH}$ energy levels, and

- The moulding water content ranges between $13.1-18.1 \%, 13.7-17.9 \%$ and $9.6-14.6 \%$ for BSL, WAS and BSH respectively.

Finally, cation exchange analysis further revealed that the inclusion of CPA reduces the hydraulic conductivity, compressibility and enhanced strength.

\section{References}

[1] AASHTO. Standard specification for transportation materials and methods of sampling and testing, $14^{\text {th }}$ Edition, Washington, D. C.; 1986.

[2] Ahmad B., Adamu U. C., Saeed M. S., Ibrahim A. I., Nasir K., and Abubakar M. "Effect of Bagasse Ash on the Properties of Cement
Stabilized Black Cotton Soil”, International Journal of Transportation Engineering and Technology. Vol. 3, Number 4, 2017, pp.67-73. doi: 10.11648/j.ijtet.20170304.14

[3] Albrecht, B. A. and Benson, C. "Effect of Desiccation on Compacted Natural Clay." Journal of Geotechnical and Geo-environmental Engineering, ASCE, Vol. 127, Number 1, 2001, pp. 67-75.

[4] ASTM C 618-15 (2015). "Standard Specification for Coal Fly Ash and Raw or Calcined Natural Pozzolan for Use in Concrete." ASTM International, West Conshohocken, PA.

[5] ASTM, (1992), Annual Book of Standards, Vol. 4(8), American Society for Testing and Materials, Philadephia.

[6] Bello A. A., Ige, J. A., and Ibitoye, G. I. "Geotechnical Properties of Lateritic Soil Stabilized with Cement-Bamboo Leaf Ash Admixture", International Journal of Applied Engineering Research. Vol. 9, Number 21, 2014, pp.9655-9665.

[7] Bello A. A., Ige, J. A., and Hammed A. "Stabilization of Lateritic Soil with Cassava Peel Ash", British Journal of Applied Science and Technology. Vol. 7, Number 6, 2015, pp.642650.

[8] BSI. Methods of Testing Soils for Civil Engineering Purposes. British Standard Institution, BS 1377, London; 1990.

[9] Edeh, J., Tyav, S., and Osinubi, K. "Cassava Peel Ash Stabilized Lateritic Soil as Highway Pavement Material", Pavement Materials, Structures, and Performance, 2014, pp. 375-382.

[10] Etim, R. K., Eberemu, A. O., and Osinubi, K. J. "Stabilization of black cotton soil with lime and iron ore tailings admixture." Transportation Geotechnics (2017), doi: http://dx.doi.org/10.1016/j.trgeo.2017.01.00 $\underline{2}$

[11]Extension Fact Sheet. "Cation Exchange Capacity." Cornell University Coorperative Extension Fact Sheet, fact sheet 22; 2007, http://www.css.cornell.edu/soiltest/ 
[12]FAO. "Save and Grow: Cassava, A guide to sustainable production intensification", Food and Agriculture Organization of the United Nations, Rome (2013), pp.1-129.

[13] Head, K. H. Manual of Soil Laboratory Testing. Volume 1: soil classification and Compaction Tests, Second Edition, Pentech Press, London; 1992.

[14] IITA. Successes and challenges of cassava enterprises in West Africa: A case study of Nigeria, Bénin, and Sierra Leone; 2009.

[15] Kharade A. S., Suryavanshi V. V, Gujar B. S., and Deshmukh R. R. "Waste Product 'Bagasse Ash' From Sugar Industry Can Be Used As Stabilizing Material for Expansive Soils", IJRET Int. J. Res. Eng. Technol., Volume 1, Number 1, 2014, pp. 506-512.

[16] Klinkenberg, K. and Higgin, G. M. "An outline of Northern Nigerian Soils", Nigeria J. Sci., Volume 2, Number 2, 1968, pp. 91-115

[17] Moses G., and Osinubi K. J. "Influence of Compactive Efforts on Cement- Bagasse Ash Treatment of Expansive Black Cotton Soil", Int. J. Civil, Environ. Struct. Constr. Archit. Eng., Volume 7 Number 7, 2013, pp. 1541-1548.

[18] Nigeria General Specification. Bridges and Road Works. Federal Ministry of Works and Housing, Headquarters, Abuja, Nigeria. Vol.11 (Revised); 1997.

[19] Ochepo, J., Stephen, O. D., and Masheye, O. "Effect of Water Cement Ratio on Cohesion and Friction Angle of Expansive Black Clay of Gombe State, Nigeria", Electronic Journal of Geotechnical Engineering, Volume 12, 2012, pp. 2599-2612.

[20] Ola, S. A. "The geotechnical properties of black cotton soils of North Eastern Nigeria." In S. A. Ola, 1983 (editor), Tropical Soils of Nigeria in Engineering Practice, A. A. Balkama, Rotterdam, 1983; pp. 160-178.

[21] Olutaiwo A.O. and Ariyo, A. "Evaluation of the Structural Performance of Lateritic Soil Stabilized with Cassava Peel Ash (CPA) and Cement", International Journal of Constructive Research in Civil Engineering (IJCRCE.), Volume 2, Number 2, 2017, pp. 18-26
[22] Oluyemi-Ayibiowo B. D. and Ola S. O. "Stabilization of Black Cotton Soils from North-Eastern Nigeria with Sodium Silicate", International Journal of Scientific Research and Innovative Technology, Volume 2, Number 6, 2015, pp. 313-328.

[23] Oriola, F. and Moses, G. "Compacted black cotton soil treated with cement kiln dust as hydraulic barrier material", American Journal of Scientific and Industrial Research, Volume 2, Number 4, 2011, pp. 521-530.

[24] Osinubi, K. J. "Lime Modification of Black Cotton Soil", Spectrum Journal, Volume 2, 1995, pp. 112-122.

[25] Osinubi, K. J. and Nwaiwu, C. M. "Design of compacted lateritic soil liners and covers." Journal of Geotech and Geoenvironmental Engineering, ASCE Volume 2, 2006, pp.203 213.

[26] Osinubi, K. J. "Stabilization of tropical black clay with cement and pulverized coal bottom ash admixture". In: Advanced in Unsaturated Geotechnics. Edited by Cheuler, D., Sandra, L. H., and Nien-Yui Chang. ASCE GSP, (99), 2000; pp. 289-302.

[27] Salau, M. A. and Olonade, K. A. "Pozzolanic Potentials of Cassava Peel Ash", Journal of Engineering Research, Vol. 16, Number 1, 2011, pp. 10-21.

Tiza M. T., and Iorver V. "A Review of Literature on Effect of Agricultural Solid Waste on Stabilization of Expansive Soil", International Journal for Innovative Research in Multidisciplinary Field, Vol. 2, Number 7, 2016, pp. 121-132. 